\title{
Case-Based Pedagogy for Teacher Education: An Instructional Model
}

\author{
Mutlu Şen Akbulut \\ Boğaziçi University, Turkey \\ ORCID: 0000-0003-1042-2517 \\ Janette R. Hill \\ The University of Georgia, USA \\ ORCID: 0000-0002-9724-2895
}

Received: 24 Jun 2020

Accepted: 2 Aug 2020

\begin{abstract}
The use of cases has been promoted as a promising instructional method for creating authentic learning environments. However, the development and implementation of the best instructional strategies for effective use of cases still require further research. This paper addresses some of these gaps by proposing an emergent instructional model to be grounded in constructivism and current instructional models for case-based pedagogy. The model was implemented in a science methods course for elementary education prospective teachers. The participants engaged in several activities for four cases such as participating in online and classroom discussions and writing reflection papers. In this paper, first, we will present the connection between the pedagogy and teacher education; second, we will introduce the theoretical framework with implications for the instructional model; then, we will present some examples of learning experiences that should be included in a constructivist case-based learning environment with the proposed instructional model. Lastly, we will present findings from a study wherein the proposed model was applied to support prospective teachers' socioscientific issue-based teaching and learning, and discuss implications for research and practice.
\end{abstract}

Keywords: case-based pedagogy, teacher education, instructional model

\begin{abstract}
INTRODUCTION
Socio-scientific issues (SSIs) are defined as controversial social problems with conceptual and/or technological relations to science (Sadler, 2004). Many researchers suggest the inclusion of SSIs in the science classrooms since the integration of SSIs that incorporate daily-life problems provides opportunities for developing scientifically-literate citizens (Driver, Newton, \& Osborne, 2000; Evagorou, Jimenez-Aleixandre, \& Osborne, 2012). This study sought to extend the research in earlier grades by preparing prospective elementary teachers to integrate SSIs in their future classrooms. By engaging SSIs in teacher education, prospective teachers will learn about this approach for their classes and appreciate the value of making science more relevant for students' lives and more connected to other disciplines.

To help prospective teachers prepare for applying their knowledge and skills in their 21st-century classrooms teacher educators should create authentic learning activities including the analysis of practice. Integrating authentic experiences of what it means to engage with SSIs in informed ways into teacher preparation is an important first step to help prospective teachers understand the value of SSI-based teaching and prepare them for potential challenges of this approach.
\end{abstract}


Socio-scientific issue-based instruction is similar in its teaching approach to case-based teaching in that they both frame science content within a story (Latourelle, Poplawsky, Shmaefsky, \& Musante, 2012). Thus, we incorporated case materials related to SSI-based teaching and learning in a constructivist case-based learning environment (CBLe) to support prospective teachers' conceptualization of socio-scientific issue-based teaching and learning (SSI-TL). The effects of the CBLe on prospective teachers' conceptualization of SSI-TL are shared in a larger study. The purpose of this conceptual paper was first, to identify critical characteristics of a case-based learning environment from the literature on case-based pedagogy; second, to operationalize strategies for effective use of cases in teacher education by designing an instructional model that incorporated the identified guidelines; and third, to portray students' experiences within the case-based learning environment.

\section{Case-based Pedagogy}

The use of cases in teacher education is accepted as a promising instructional method for creating authentic learning environments (Koury et al., 2009; Levin, 2001; Lundeberg, Levin, \& Harrington, 1999). Case-based pedagogy emulates real classroom environments, and thus enables students to think like teachers (Shulman, 1992). However, development and implementation of best instructional strategies for effective use of cases still require further research (Zottmann et al., 2012) since most published studies "describe the potential of the approach and provide descriptions of case systems" (Fitzgerald et al., 2009, p. 32) without providing strong empirical evidence.

The use of cases in teacher education is an effective pedagogical strategy because cases provide an opportunity for understanding the multifaceted nature of teaching and learning (Tippins, Nichols, \& Dana, 1999). With case-based learning (CBL), students develop higher-order thinking and reflection skills by reading and discussing complex, real-life scenarios (Butler, Lee, \& Tippins, 2006).

Unsurprisingly, since the 1990s, advocates of case-based teaching have produced a large body of literature highlighting its advantages (e.g. Harrington, 1995; Lundeberg et al., 1999; Shulman, 1991). However, there are many challenges regarding case-based learning (CBL). A well-written story is not sufficient for successful CBL. There are several core attributes of successful cases such as being: (a) relevant, (b) authentic, (c) engaging, (d) instructional (Kim et al., 2006). There is a variety of approaches to developing and using classroom cases in teacher education (Bryan \& Tippins, 2006; Merseth, 1996), thus it is important to choose appropriate cases for your targeted educational outcomes and adapt the cases to include these core attributes.

Furthermore, prospective teachers may start with predispositions toward simplifying the situation and identifying issues from a single perspective when they engage in a case reading. Prospective teachers' reflective and critical thinking skills can be facilitated through discussions of the case (Butler et al., 2006; Ertmer \& Koehler, 2015). Online or face-to-face discussions play a very important role to be able to provide opportunities to analyze case dilemmas from various perspectives and to restructure prospective teachers' beliefs about teaching and learning. However, McLoughlin and Mynard (2009) noted that providing a course material in an online platform may not result in higher levels of thinking.

There are several studies reporting the effects and comparisons of online and face-to-face case discussions in the literature (Ertmer \& Koehler, 2015; Mitchem et al., 2008; Weil, McGuigan, \& Kern, 2011). Ertmer and Koehler (2018) stated that the structure and facilitation of the discussion, as well as guiding questions and responses by the facilitator should be specifically designed to provide effective case-based discussion experiences. In this study, both online and in-class discussions are viewed as the primary tools to enhance students' learning (Ertmer \& Koehler, 2015; Levin, 1995). Considering the increasing demand for online and blended learning experiences of university students, today's teacher educators must be well-equipped in guiding discussions in both face-to-face and online contexts (Ertmer \& Koehler, 2018).

Despite the challenges in case-based teaching and learning, many studies reported the benefits of using casebased pedagogy in teacher education (Angeli, 2004; Butler et al., 2006; Choi \& Lee, 2009; Kim \& Hannafin, 2008; Yoon et al., 2006); however, the lack of resources and instructional models to support teachers' and 
curriculum designers' work toward creating case-based learning experiences is a primary constraint limiting the widespread use of the approach (Fitzgerald et al., 2009; Grossman, 2005; Zottmann et al., 2012).

This paper addresses some of these gaps by proposing an emergent instructional model to be grounded in constructivism and current instructional models for case-based pedagogy (see Hemphill, Richards, Gaudreault, \& Templin, 2015; Kim et al., 2006). We present the instructional model that guided us in developing a case-based learning environment, its learning activities, and the participants' perceptions of the model in the following sections.

\section{THEORETICAL FRAMEWORK}

Foundational learning theories provide the basis for understanding learning and for designing effective learning environments. To assess the impact of case-based pedagogy, research designs should be built on educational theories of student learning and researchers should question how cases are potentially affecting students (Lundeberg \& Yadav, 2006). Without understanding the case-based pedagogy from supporting learning theories, analyzing its challenges, and identifying effective ways to use it would be impossible (Kantar, 2013).

Case-based pedagogy is supported by constructivism (Hartfield, 2010) and by several other theories, including cognitive flexibility and situated cognition (Blackmon, Hong, \& Choi, 2007). The proposed model is drawn from constructivism and its instructional principles. Savery and Duffy (1996) defined constructivism as a philosophical view of how we come to understand or know. This philosophical view is commonly referred to as constructivist theory because "constructivism makes general predictions that can be operationalized and tested" (Schunk, 2008, p. 38). There are three key assumptions that characterize a constructivist philosophical view. Savery and Duffy (1996) describe these assumptions as follows:

1. Knowledge is constructed from our experiences. What we understand stems from our interactions with the content and the context.

2. Cognitive dissonance is the catalyst for meaning construction and determines the organization and nature of what is learned.

3. People should be active in their learning process to be able to produce knowledge based on their beliefs and experiences in situations, which differ from person to person (Schunk, 2008). Thus, knowledge evolves through social negotiation.

These tenets provide the foundation for constructivist learning theory. However, constructivism is not a unified theory (Schunk, 2008), and these tenets may be conceptualized differently in different types of constructivism (e.g., radical, cognitive, contextual, or social constructivism). For example, social constructivism emphasizes the importance of social negotiation and culture on knowledge construction more than any other type of constructivism (Derry, 1999). While creating our design principles, we tried to bring different perspectives of constructivism together to develop a better approach for the learning environment. This concept of 'developing learning environments' and its connection to constructivism are presented in the next section.

\section{Developing a Constructivist Case-based Learning Environment}

Wilson (1996) describes a constructivist learning environment as "a place where learners may work together and support each other as they use a variety of tools and information resources in their guided pursuit of learning goals and problem-solving activities" (p. 5). College educators are recommended to design constructivist learning environments to allow learners to become active builders of knowledge so that they can become lifelong learners (Sursock, Smidt, \& Davies, 2010).

To be able to design effective constructivist learning environments, it is important to understand the link between theory and practice. Constructivist educational researchers created many pedagogical strategies to apply in teaching and learning (Brooks \& Brooks, 1993; Driscoll, 1994; Jonassen, 1991). The general 
theoretical and practical constructivist consensus indicates that several core design principles are essential in constructivist pedagogy (Brooks \& Brooks, 1993; Honebein, 1996; Savery \& Duffy, 1996). We will explain some of these principles and how they inform the model in the following sub-sections.

Design principle 1: Embed learning in authentic and relevant contexts. We learn to be able to function more efficiently in our world (Savery \& Duffy, 1996). The purpose of any learning activity should be clear, and learners should perceive and accept its relevance to their lives. For the social constructivists, authentic experiences are very important because the individual may construct knowledge personally and mediate that knowledge socially when we engage in authentic experiences (Doolittle \& Camp, 1999).

To provide authentic activities, the case-based learning environment should encourage learners to focus on the complexity and uncertainty of the real-world example. The learners should be provided with a role in "selecting which information is relevant and finding a solution which suits their needs" (Herrington \& Oliver, 1995, p. 257). More details about learning experiences that were featured in the learning environment are presented in the Instructional Design Framework section.

Design principle 2: Embed learning in social experience. Constructivism suggests that social interaction facilitates the development of socially relevant skills and mediated knowledge in terms of what is already known (Tobin \& Tippins, 1993). As an individual construct understanding in a social experience, this experience may validate her knowledge structures, or it may contradict those structures. The importance of a learning community where ideas are discussed and understanding deepened is critical to the design of an effective learning environment (Savery \& Duffy, 1996). Thus, the learning environment should encourage collaboration between all individuals in a learning community (i.e., teachers and students or students and students). The proposed model incorporates this principle by facilitating collaboration between students by requiring them to prepare for analyzing via online discussions and sharing different perspectives during inclass discussions, and then suggesting a final solution and reflection on the proposed solutions.

Design principle 3: Provide experience in testing ideas against alternative views and encourage multiple perspectives. In social constructivism, there is no special "truth," just perceptual understandings that may transpire being more suitable. In this context, knowledge is socially negotiated (Savery \& Duffy, 1996). Problems in a real-world context rarely have one exact answer. Thus, opportunities to engage in activities that enable individuals to evaluate alternative solutions as a means of evolving their knowledge should be provided in constructivist learning environments (Honebein, 1996).

Exploring an experience from multiple perspectives provides the student with a greater opportunity to develop a more viable model of their experiences and understanding (Doolittle \& Camp, 1999). This principle has two implications for this study: (a) Case materials should allow learners to curate information from different sources and examine issues from a variety of perspectives (Morrow, Epling, Terán, Sutphen, \& Novick, 2003), and (b) Case materials should allow for multiple correct responses and decision-making opportunities. The instructor should make sure to ask guiding questions to consider different perspectives during online and in-class discussions. This principle also has a strong connection to one of the practices of socio-scientific reasoning, which is assessing issues from multiple perspectives (Sadler, 2014).

Design principle 4: Provide opportunities for reflection. The underlying view of constructivism assumes that learners are active in their construction of knowledge and meaning (Doolittle \& Camp, 1999). The key outcome of this activity involves "students" ability to explain why and how they solved a problem in a certain way; to analyze their construction of knowledge and processes" (Honebein, 1996, p. 12). Student thinking needs to be supported by providing time to think and evaluate the adequacy of required knowledge, create connections to previous experiences, clarify their thinking processes.

This principle was incorporated in the case-based learning environment by requiring students to reflect upon the whole process of their learning experience, and on their proposed solutions (Blackmon et al., 2007). Guiding questions for the final analysis of the cases after online and classroom discussion provided opportunities to reflect by asking students how their initial ideas evolved, and individual interviews included questions about students' reflections on their learning experience with cases. 
Design principle 5: Challenge and support the learner's thinking by creating cognitive conflict. Since social constructivism avoids any direct knowledge of reality, the primary role for the teacher is to guide students to an awareness of their experiences and socially agreed-upon meanings (Doolittle \& Camp, 1999). The teacher plays multiple roles in a case-based learning environment such as challenging, supporting, and guiding but not leading to a specific conclusion. This does not mean that any activity or any solution is adequate. Instructors should value as well as challenge learners' thinking (Savery \& Duffy, 1996).

These five principles tremendously informed the instructional model, which we present in the following section. Based on these principles, we see this instructional model as a guide to develop a case-based learning environment consisting of selected information resources (e.g. case studies related to authentic socioscientific issues) to pursuit targeted learning goals (e.g. conceptualization of SSI-based teaching and learning).

\section{INSTRUCTIONAL MODEL}

Instructional models propose how to combine sets of different instructional strategies to create instructional activities. There are different ways to plan instructional activities in a case-based learning environment (Choi \& Lee, 2009). Effective instructional models are based on learning theories, accordingly, we draw from Harrington and Garrison's (1992) concept of cases as shared inquiry and the aforementioned instructional principles of constructivism. The current model comprises two sections: 1) design principles informing the development of a case-based learning environment and 2) learning experiences in a shared inquiry process (see Figure 1 and Sen (2017) for details).

In line with the constructivist roots of case-based learning, cases as shared inquiry approach requires collaboration between the instructor and students. Hemphill et al. (2015) listed common strategies used in this approach as (a) providing individual time for reflection, (b) engaging in group discussions, (c) sharing ideas, and (d) reflecting on the learning process. In the following sections, we explain how we integrated these strategies and case-based learning activities in the proposed model.

\section{Phase 1: Inquiry Focus}

The first phase of a shared inquiry process is selecting a focus for the inquiry. While the focus could be anything that requires inquiry, a case can be used to initiate the shared inquiry (Harrington \& Garrison, 1992; Hemphill et al., 2015). To increase students' interest and engagement in the inquiry process, case materials should be relevant and authentic (Morrow et al., 2003). Authenticity can be increased when cases incorporate the tasks, information, and problem-solving opportunities that mirror the real-life situations in which the knowledge will be used in future practice (Brown, Collins, \& Duguid, 1989; Herrington \& Oliver, 1995).

To provide authentic activities, design principle one should be taken into consideration. Kim et al. (2006) stated that to make a case content rich and complex, multiple correct responses, decision-making opportunities, and explanations should be included. During the implementation of the model in this study, we provided cases of real teachers' classroom experiences which include dilemmas of socio-scientific issuebased teaching and relevant SSI cases to students' daily lives (e.g. Appendix B, Zika virus case) for sustained interest and motivation.

\section{Phase 2: Space and Time for Consideration}

In phase two, open space and time should be set for students (Hemphill et al., 2015) in order to consider initial ideas and solutions to the case. Thus, in the proposed case-based learning environment, the course instructor should provide guiding questions for the case, and students should engage in online discussions to respond to those questions and share their opinions prior to class discussions. This is very important to help students identify potential problems within the case and to reflect on potential solutions or plans of action (Mostert, 2007). 


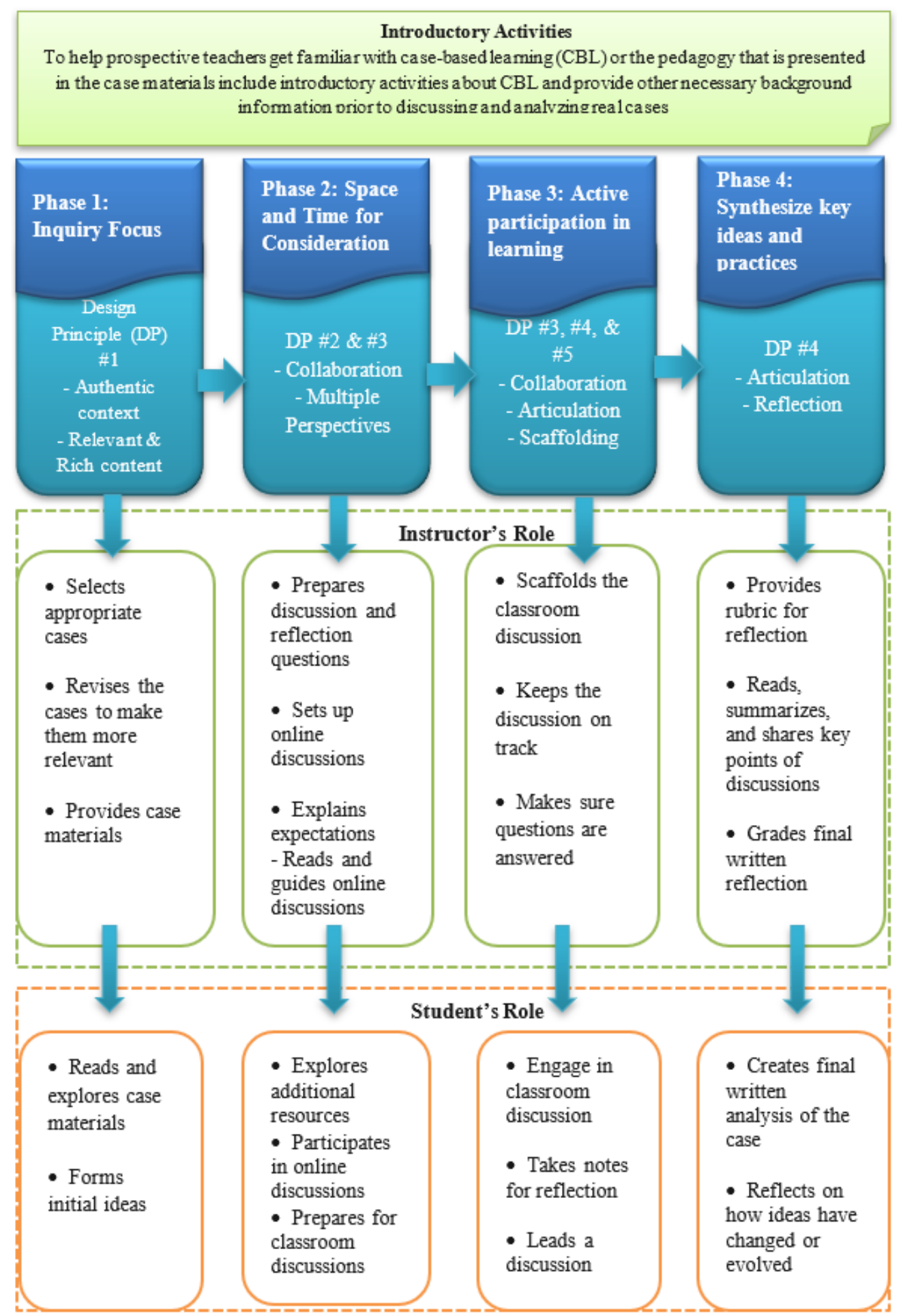

Figure 1. An instructional model for a constructivist case-based learning environment

The proposed case-based learning environment supports collaboration between students who are required to prepare for, analyze, discuss a case, and then suggest a potential solution. This includes responding to other students' online discussion posts to challenge their opinions and/or assumptions. Engaging in the online discussion and the classroom discussion, and the final analysis of the case also provide an opportunity for investigating multiple perspectives (Herrington \& Oliver, 1995). Additional resources add at the end of the cases would also help students to curate information from multiple resources and explore problems from a variety of perspectives (Kim et al., 2006; Morrow et al., 2003). 


\section{Phase 3: Active Participation in Learning}

In phase three, opportunities to become active members of the inquiry process should be provided to each student in the learning environment. In the proposed design, students express their ideas either out-loud (in classroom discussions), or in writing (in online discussions and case reflection papers).

Tippins, Koballa, and Payne (2002) suggested that case discussion facilitates the investigation of critical issues in teaching and learning through actively taking on multiple perspectives. Classroom discussion is really important because peer interactions are enriched by their prior knowledge, experiences, and interests that the students bring to the process. The collaboration between students provides opportunities for students to examine their own thought processes (Goodman, Soller, Linton, \& Gaimarie, 1998).

To foster knowledge construction, the designed learning environment ensures that the cases are used within a social context; thus, students work in groups, discuss the issues, lead a classroom discussion session, and present multiple perspectives both from case content and online discussions. Through these activities, learners have the opportunity to articulate, negotiate, defend, and evaluate their knowledge (Herrington \& Oliver, 1995).

\section{Phase 4: Synthesize Key Ideas and Practices}

The instructor plays multiple roles in the proposed case-based learning environment. The instructor summarizes key issues and asks questions that help students identify issues during the application of proposed activities. Scaffolding student discussion on online platforms or in class is not an easy job. Thus, teachers should focus on helping students to investigate others' solutions and discuss the case in manners that expand their learning (Blackmon et al., 2007).

In the proposed design, students write a reflection of insights, opinions, and potential solutions they have gathered from their initial preparation as modified by the online and face-to-face discussions. General guiding questions should be provided such as to prompt prospective teachers to consider their final suggestions to the challenges that were faced by the teacher or the SSI; how they would act if they faced similar challenges; and how their initial ideas evolve after discussions.

\section{METHODOLOGY}

This paper presents an instrumental case study (Stake, 1995) of the implementation of a new case-based learning environment in the teacher preparation program context. An instrumental case study approach uses a particular case to gain insight into an issue and/or test established points of view about these issues (Bullough Jr., 2015). According to Stake (1995), such case studies are utilized when there is a "research question, a puzzlement, a need for general understanding," (р. 3). Generally, instrumental cases have limited generalizability. However, we selected the instrumental case study design because there was a need for general understanding regarding the use of the instructional model for a case-based learning environment in the teacher preparation program context. To this end, this instrumental case study of was focused to: a) develop a feasible instructional model for a case-based learning environment that incorporated cases related to socio-scientific issues, and b) apply the model to explore prospective teachers' experiences with the incorporating learning activities in an elementary science methods course. The overarching research question that guided this study is as follows: How do prospective teachers perceive their learning experiences in a specifically designed case-based learning environment based on the proposed instructional model?

\section{Context and Participants}

In the USA, students enrolled in the elementary education programs prepare for a career teaching prekindergarten through grade five. Students take a range of coursework, including educational theory, elementary curricula, and methods courses in language, literacy, mathematics, science, and social studies. Students usually get hands-on experience with different student populations thanks to universities' partnerships with several local school districts. The proposed model was implemented in a required 
Table 1. Details about the Participants

\begin{tabular}{|c|c|c|c|c|}
\hline Participant & Gender & Department/Year & Prior SSI Experience & Prior CBL Experience \\
\hline Alex & Female & $\begin{array}{l}\text { 3rd-year Elementary } \\
\text { Education Student }\end{array}$ & $\begin{array}{l}\text { Discussion of current issues in high school. } \\
\text { (Not in-depth) }\end{array}$ & None \\
\hline Erica & Female & $\begin{array}{l}\text { 3rd-year Elementary } \\
\text { Education Student }\end{array}$ & $\begin{array}{l}\text { Discussion of social issues in college-level } \\
\text { pedagogy course (Not in-depth) }\end{array}$ & $\begin{array}{l}\text { Inclusion of a short } \\
\text { story in a class }\end{array}$ \\
\hline Kyla & Female & $\begin{array}{l}\text { 3rd-year Elementary } \\
\text { Education Student }\end{array}$ & None & None \\
\hline Mary & Female & $\begin{array}{l}\text { 3rd-year Elementary } \\
\text { Education Student }\end{array}$ & $\begin{array}{l}\text { Discussion of current issues in college- } \\
\text { level pedagogy course (Not in-depth) }\end{array}$ & None \\
\hline
\end{tabular}

undergraduate science methods course for elementary education at a major southern U.S. university. The class is comprised of 26 juniors enrolled in the elementary education program. Participants had already involved in elementary classrooms where they observed, assisted teachers, work with children but have not completed their full-time student teaching experience during the implementation of this study.

The science methods course is designed in a way to provide prospective teachers with opportunities to build a vision of constructivist elementary science teaching and learning in this study. During the semester students involved in independent and group course activities including reading a book titled Last Child in the Wood and preparing a presentation on one chapter, creating a citizen science project, and hands-on instructional material development activities during class hours.

For the purposes of this research, the participants engaged in several activities for four cases such as participating in online and classroom discussions and writing reflection papers (see Appendix A for details) and these activities comprised $50 \%$ of their course grade. We asked students to voluntarily participate in interviews to share their experiences and perceptions about the instructional model. Four primary participants were purposefully selected from among eight interview volunteers because they worked as a group throughout the semester. Table 1 summarizes participant profiles.

\section{Materials and Methods}

For the implementation of the instructional model in a science methods course for elementary teacher education program, we adopted cases to provide opportunities with analysis and reflection. We used two cases on real-life, socioscientific issues and two pedagogical cases that present the dilemmas of teaching and learning of socio-scientific issues in the classrooms. With these purposes, we integrated case-based activities including open-cases of practicing teachers that the first author adapted from Tippins, Koballa, and Payne's (2002) book, and dilemma cases adapted from the National Center for Case Study Teaching in Science.

Before class discussions, all prospective teachers were required to read the case material, respond to online discussion questions to think critically about the problems and possible solutions. Online prompts included general reflection questions to explore students' conceptualization of SSI-based teaching. The instructor facilitated both online and in-class discussions and the researcher was an observer throughout the implementation. Students read two cases on authentic socio-scientific issues and two pedagogical cases that presented the dilemmas of teaching and learning of socio-scientific issues in the classroom. Participants wrote case reflections after completion of online and in-class discussions for each of the four cases.

\section{Data Analysis}

To explore the effectiveness of the instructional model, we conducted all of the interviews toward the end of the semester, after the primary participants completed all instructional activities. The duration of the interviews varied between 30 and 45 minutes. The first author audio-recorded all interviews with the participants' permission. A professional transcribed the interviews verbatim for analysis. We reviewed all transcriptions for accuracy, added missing text, and revised misspelled areas of the transcripts in preparation for data analysis. The interview transcripts provided primary data for this study. The data were analyzed using the constant comparative method (Strauss \& Corbin, 1994) to create final categories. Results from the 
analysis indicated that the participants appreciated the designed case-based learning environment (CBLe) as they interpreted the learning experiences as a way to enhance their conceptualization of SSI-based teaching and learning for several reasons that we will present in the following sub-sections.

\title{
FINDINGS
}

\section{Importance of Authentic Context}

The importance of having authentic context for cases was discussed in the theoretical framework section and participants' expressions of their experiences with the cases supported this idea. All of the participants mentioned ideas related to "the benefits of the current and relevant nature of the cases" (e.g., promoting understanding, making learning interesting, enhancing engagement). For example, with respect to making learning more interesting, Alex shared that CBL helped her to:

\begin{abstract}
... kind of wrap my mind around the real life of the issues. You learn about history as history and you don't kind of put it in a real-life perspective. And so, I think the CBL really helped me to talk about the controversial issues and talk about the Zika virus and talk about genetic testing but realize that it also is happening. It's not just some story, so our actions can affect it in a negative or positive way.
\end{abstract}

Participants also shared their appreciation for the authenticity of the cases, especially for the SSI cases. For example, during the interview, Kyla shared that she found the Zika Case (the first SSI case) very interesting and she liked being able to research it herself since it is currently happening. She also shared that she thought the case activities were more helpful for her understanding of SSIs than other activities (e.g., in-class activities).

Mary also mentioned that the current and relevant nature of the Zika Virus topic inspired her as a teacher to discuss these issues in the future. She shared how helpful the case was in improving her understanding of different perspectives and the importance of enhancing her future students' understanding of other perspectives when she teaches these issues.

The prospective teachers also explained that the current nature of the cases enhanced their understanding as they engage in online discussions and reflection papers. For example, one of the prospective teachers mentioned that "I didn't really pay attention to the news about the virus but learned a lot through reading the case" during the online discussions for the first SSI case. Students shared their interest in the second SSI case (Genetic Testing) and expressed that the authenticity of the case made it more engaging. For example, many students shared that the case reminded them of a modern movie (My Sister's Keeper - released in 2009) and stated that it was interesting to see that issues related to genetic testing were currently happening on a daily basis. All of the points highlighted here suggest that the current and relevant nature of the cases enhanced participants' conceptualization of SSIs.

\section{Benefits of Discussion Activities}

All of the primary participants shared their appreciation for the discussion activities we had for each case. Many other participants expressed their opinions about discussions (online or in-class) and how those activities helped them to improve their conceptualization of the issues and/or further develop their initial ideas. Primary participants mentioned many ideas related to "the benefits of discussions" (e.g., promoting understanding, encouraging exploration, the importance of discussion to understanding other perspectives) throughout the interviews.

For example, regarding the benefit of understanding other perspectives, Alex shared that "Some of the discussions and things we had brought up challenges that I didn't originally anticipate. So having a lot of different brains going around and having the online discussions are super helpful". Kyla also mentioned that she learned from her peers and discussions helped her to think about other perspectives. She shared that: 
I've liked the discussions we've had, I thought it has been helpful to understand how other people learn and how other people take things. And there's a lot of times where I would be able to take what someone else said and add that to my reflection which was good to know that I'm learning from my peers and not just my teacher.

Mary also elaborated on the importance of discussions, focusing on the in-class discussion. She stated that not having the discussions would affect the efficacy of the instructional model. She shared that:

I liked that we were able to do it individually at first and form our own opinions... and then
I would go into the classroom and kind of see how other people's opinions differed from
my opinions. So I enjoyed being able to talk about the case with other people because my
initial reaction on how I think I would have solved it normally changed after all of those
discussions. I think it would be not efficient if we just got the case and had to give you our
response ourselves.

This excerpt suggested that discussion activities were helpful for enhancing students' initial conceptualization of the cases. Regarding the importance of in-class discussions, Alex mentioned ideas related to considering other perspectives and backing up your opinions. She stated that:

I think the most helpful for me was the in-person class discussions. It was not only giving you the opportunity to share your point of view, but to hear others' points of view. And it also helped with the social skills of just being able to have a conversation and being able to back up opinions while still respecting other people's opinions.

Similar to Alex and Mary, Kyla mentioned that she appreciated in-class discussions more than online discussions. Other participants also shared that they enjoyed the in-class discussion activities more than online discussions because they were able to hear all of their classmates' opinions, and it was a more active learning experience. However, they also expressed their appreciation for online discussions and stated that they found online discussions beneficial for several reasons such as preparing for classroom discussions and written reflections. Other participants also shared that writing the online discussion posts helped them to formulate their thoughts and improve their opinions in their posts or reflections.

These results indicated that even though participants expressed that they favored in-class discussions, they were able to identify the importance of having online discussions. The difference between the quality level of primary participants' online discussion posts and reflections papers also suggests that discussions were helpful in promoting prospective teachers' conceptualization of SSIs which will be reported in a further paper. Participants viewed their experiences with discussion activities as beneficial and important for several reasons, and appreciated having both online and in-class discussions.

\section{Being Prepared for Future Challenges}

The primary participants also appreciated the designed CBLe as they interpreted the learning experiences as a way to enhance their conceptualization of SSI-based teaching. All of them expressed that they felt more prepared for teaching SSIs in their future classrooms. Many other participants expressed their appreciation in their online discussion posts and reflection papers. For example, Erica stated that:

I know that it's not going to be easy and it's going to take time and I'm going to have to sit down and really think about what I'm doing, and even having to defend myself. But I feel prepared now that just being in this class and going through the different issues and seeing how it brings up like ethical issues and moral issues and different views of society.

Kyla also shared that she was "ready to fail" but that the cases helped her to think about challenges that she had never thought about before. She mentioned the importance of being careful about controversial issues and knowing the background of students as you bring these issues into the classroom, which were ideas we discussed in class for the first pedagogy case. 
Mary shared her feelings of nervousness about potential challenges she may face in the future but she also mentioned many positive opinions about how cases helped her to prepare for future challenges. Similar to Erica, Mary shared that she felt as prepared as possible before actually experiencing the teaching of an SSI.

These findings suggested that all participants felt more prepared for facing possible challenges of teaching SSIs and expressed their enthusiasm to integrate SSIs in their future classrooms after engaging in activities in the designed case-based learning environment.

\section{Suggestions for the Model}

To explore how prospective elementary teachers described their experiences with the CBLe, we included open-ended questions about their positive and negative experiences with the activities, and asked for possible suggestions to improve the instructional model during the interviews. The primary participants mentioned several ideas related to the benefits of the activities, challenges of CBL, and suggestions for the model (e.g., such as adding more cases, giving less time for the reflection papers.) First of all, participants appreciated the case-based pedagogy in general and thought that other teacher education courses could use this method. For example, Kyla stated that:

\section{Social studies could definitely benefit from it because it was a lot about how we teach social studies in the classroom and a lot of that is controversial too... how you teach slavery or how you do different topics that may be difficult.}

Throughout the interviews, all participants expressed their general appreciation of the case-based pedagogy and activities we had, especially the discussion activities. To better explore any negative experiences or activities that can be improved, we asked open-ended questions such as "Which activities hindered your learning?". All participants shared that nothing hindered their learning but three of them stated that writing the reflections was repetitive or frustrating, even though they had some positive opinions about this particular instructional activity.

On the other hand, Kyla was also one of the prospective teachers who shared that her favorite activity was in-class discussions but she also noted that she found writing the reflections quite helpful. The points that the primary participants made here suggest an important implication for the design of the activities. As we developed the syllabus, we gave students one week to write their reflections after the classroom discussion, and this may be changed in future implementations. We still think writing reflections is an important component of the instructional model developed for this study since participants presented more comprehensive conceptualizations of the cases in their reflection papers compared to their online discussion posts.

This finding suggests that writing the reflections helped students synthesize their initial ideas and develop more complex conceptualizations of SSIs or SSI-based teaching. For example, Mary expressed her experiences with writing the reflections as very positive and shared that:

I liked writing the reflection just because it was reiterating what you had learned. So, in the classroom discussion, because I knew that I would have to reflect later, it caused me to like take notes and things. And since I do learn when I'm talking or writing, talking about it and then writing down those new ideas and then reflecting on it, I think it embedded that back into my mind.

Similar to Kyla and Mary, many other students shared positive opinions about the benefits of writing reflections such as improving their writing skills, articulating ideas, and summarizing what they learned through this writing task. Participants' evaluation of reflection papers in terms of their conceptualization of SSIs and SSI-based teaching are shared in a different paper in detail. 


\section{DISCUSSION AND IMPLICATIONS}

In this paper, case-based pedagogy has been discussed with a strong connection of constructivism to support prospective science teachers' socio-scientific issue-based teaching and learning. The literature on case-based learning in teacher education context was reviewed and empirical research has been explored to find current gaps in our understanding. A lack of effort to prepare prospective teachers for using SSI in their future classrooms is evident in the science teacher education research. This study aimed to fill some of these gaps by proposing an instructional model to support teacher educators' work toward creating case-based learning experiences.

Even though case-based pedagogy has been intensively used in medical and business education fields especially in the last decade, more exposure to case-based experiences can also provide many benefits to prospective teachers. All participants of this study stated that they were motivated to engage in reading more cases about SSI-based teaching and learning. The participants of the study suggested that case-based pedagogy can be useful in many other teacher education program courses such as social sciences and math as the pedagogy makes learning more interesting and engaging with providing authentic context. Similar to the findings of this study, participants usually enjoy CBL experiences and use adjectives such as fun and engaging when they describe their experiences with case-based pedagogy (Krupat, Richards, Sullivan, Fleenor, \& Schwartzstein, 2016). Cases with different moral controversies may bring different cultural influences of prospective teachers with different backgrounds into the scene. In the context of the study, the second SSI case (i.e., Genetic Testing) included a very controversial topic and led to a very engaging classroom discussion. The prospective teachers had different ethical considerations about the issue and their backgrounds affected their proposed solutions. In a further study, researchers may work with prospective teachers who have limited experience with SSIs and engage them in more SSI cases throughout their science methods courses and explore their moral reasoning, argumentation skills, and/or content related outcomes.

The primary participants also shared that they favored in-class discussions because it was easier to understand their peers' perspectives when they were simultaneously talking on the topic. Strangeways and Papatraianou (2016) also reported similar results in terms of discussion activities. Their findings indicated that engaging in case-based activities helped prospective teachers develop multi-perspective thinking practices overall, however asynchronous nature of online discussions "made it hard for them to suspend their reactive judgments and move away from their own perceptual position" (p. 129). Saltan, Özden, and Kiraz (2016) also reported that almost all students wrote their ideas shortly even though "almost all students expressed that this environment was helpful in terms of gaining different perspectives" (p.21). Furthermore, their results also supported that the asynchronous nature of online discussions made it difficult to create a discussion atmosphere because students rarely attended the same steps at the same time. These results point out an important implication for design to better embed pedagogical supports and timely structures for online discussion activities.

Both online discussions and in-class discussions were important components of the instructional model in this study. Findings suggested that participants usually focused on providing their own perspective in online discussions but they were able to consider multiple perspectives after in-class discussions. The lack of ability to consider multiple perspectives was especially evident in the first online discussion activity (Zika Virus case) when most of the prospective teachers considered some pros and cons but ultimately framed the issue being relatively simple with a single solution. However, after the classroom discussion, many of the prospective teachers reflected on how their ideas had evolved and acknowledged that the topic (Zika virus issue) was more complex than they initially thought. The participants were then able to assess the issue from multiple perspectives including the ones we discussed in class.

Choi and Lee (2009) reported similar results in terms of their participants' evolution of problem-solving skills regarding complexity and multiple perspectives aspects. They stated that participants "began with tendencies to simplify the given situation and identify problems from a single perspective, mainly the teacher's perspective" (p. 123). However, similar to this study, their participants started to understand the 
complexity of cases and recognized the different interpretations of issues from multiple perspectives throughout the implementation of case activities.

In this study, the primary participants presented the highest levels of conceptualization regarding the perspectives aspect in both SSI case reflections supporting the assertion that case-based learning is an effective pedagogy for enhancing prospective teachers' ability to consider multiple perspectives. On the other hand, instructors should be considerate about the due dates and length of the reflections so as not to hinder students' learning or motivation. Participants of this study shared that reflections were 'a little repetitive' after engaging in both online and in-class discussions. For example, instructors could set up the due dates for a time (such as 48 hours) closer to the classroom discussion and encourage students to take notes during online and in-class discussions and write their reflections as soon as possible using their notes from the discussions.

\section{CONCLUSION}

Engaging in effective instructional activities and being exposed to constructivist pedagogies do not necessarily mean that teachers will be able to transform their understanding into practice and use these pedagogies in their classrooms. On the other hand, all participants shared they feel more prepared to teach relevant socio-scientific topics and shared their intent to use these materials in real classrooms, leaving us hoped that prospective teachers' "alteration of beliefs may later have a positive impact on their teaching practice" (Butler et al., 2006, p. 25).

This proposed model supported the idea that face-to-face discussions provide more social opportunities for students to construct shared-understandings and to consider multiple perspectives (Mazzolini \& Maddison, 2007). Further research can be conducted on different ways to design more efficient online discussion activities to promote considering different perspectives. Ertmer and Koehler (2018) stated that "face-to-face facilitation strategies can successfully transfer across contexts by modifying existing strategies to capitalize on the unique affordances of the online environment" (p. 662). In this study, only 26 prospective teachers were enrolled in the science methods course, thus we were able to provide additional guidance for each student and implement in-class discussions after online discussions. However, different implementation scales will likely require careful consideration of instructional strategies for both instructors and student participants. CBL can be implemented across different scales using only one type of discussion if necessary facilitation strategies are adapted and effectively used to promote shared-understanding in a learning community.

\section{REFERENCES}

Angeli, C. (2004). The effects of case-based learning on early childhood pre-service teachers' beliefs about the pedagogical uses of ICT. Journal of Educational Media, 29(2), 139-151. https://doi.org/10.1080/1358165042000253302

Blackmon, M., Hong, Y., \& Choi, I. (2007). Case-based learning. In M. Orey (Ed.), Emerging perspectives on learning, teaching, and technology. Retrieved from http://epltt.coe.uga.edu/

Brooks, J. G., \& Brooks, M. G. (1993). Becoming a constructivist teacher. In Search of understanding: The case for constructivist classrooms (pp. 101-118). Alexandria, Va.: Association for Supervision and Curriculum Development.

Brown, J. S., Collins, A., \& Duguid, P. (1989). Situated cognition and the culture of learning. Educational Researcher, 18(1), 32-42. https://doi.org/10.21236/ada204690

Bryan, L. A., \& Tippins, D. J. (2006). Employing case-based pedagogy within a reflection orientation to elementary science teacher preparation. In Appleton, K. (Ed.), Elementary science teacher education: International perspectives on contemporary issues and practice (pp. 299-315). Mahwah, NJ: Lawrence Erlbaum. 
Bullough Jr, R. V. (2015). Differences? Similarities? Male teacher, female teacher: An instrumental case study of teaching in a Head Start classroom. Teaching and Teacher Education, 47, 13-21. https://doi.org/10.1016/j.tate.2014.12.001

Butler, M. B., Lee, S., \& Tippins, D. J. (2006). Case-based methodology as an instructional strategy for understanding diversity: Preservice teachers' perceptions. Multicultural Education, 13(3), 20-26.

Choi, I., \& Lee, K. (2009). Designing and implementing a case-based learning environment for enhancing illstructured problem solving: Classroom management problems for prospective teachers. Educational Technology Research and Development, 57(1), 99-129. https://doi.org/10.1007/s11423-008-9089-2

Derry, S. J. (1999). A fish called peer learning: Searching for common themes. In A. M. O'Donnell, A. King, A. M. O'Donnell, A. King (Eds.), Cognitive perspectives on peer learning (pp. 197-211). Mahwah, NJ: Lawrence Erlbaum.

Doolittle, P. E., \& Camp, W. G. (1999). Constructivism: The career and technical education perspective. Journal of Vocational and Technical Education, 16(1), 23-46. https://doi.org/10.21061/jcte.v16i1.706

Driscoll, M. (1994). Psychology of learning for instruction. Boston: Allyn and Bacon.

Driver, R., Newton, P., \& Osborne, J. (2000). Establishing the norms of scientific argumentation in classrooms. Science Education, 84, 287-312. https://doi.org/10.1002/(sici)1098-237x(200005)84:3<287::aidsce1>3.0.co;2-a

Ertmer, P. A., \& Koehler, A. A. (2015). Facilitated versus non-facilitated online case discussions: Comparing differences in problem space coverage. Journal of Computing in Higher Education, 27(2), 69-93. https://doi.org/10.1007/s12528-015-9094-5

Ertmer, P. A., \& Koehler, A. A. (2018). Facilitation strategies and problem space coverage: Comparing faceto-face and online case-based discussions. Educational Technology Research and Development, 66(3), 639-670. https://doi.org/10.1007/s11423-017-9563-9

Evagorou, M., Jimenez-Aleixandre, M. P., \& Osborne, J. (2012). 'Should we kill the grey squirrels?' A study exploring students' justifications and decision-making. International Journal of Science Education, 34(3), 401-428. https://doi.org/10.1080/09500693.2011.619211

Fitzgerald, G., Koury, K., Mitchem, K., Hollingsead, C., Miller, K., Park, M. K., \& Tsai, H. H. (2009). Implementing case-based instruction in higher education through technology: What works best? Journal of Technology and Teacher Education, 17(1), 31-63. https://www.learntechlib.org/primary/p/26251/

Goodman, B., Soller, A., Linton, F., \& Gaimarie, R. (1998). Encouraging student reflection and articulation using a learning companion. International Journal of Artificial Intelligence in Education, 9, 237-255. https://doi.org/10.1007/s40593-015-0041-4

Grossman, P. (2005). Research on pedagogical approaches in teacher education. Studying teacher education: The report of the AERA panel on research and teacher education, 425-476.

Harrington, H. L. (1995). Fostering reasoned decisions: Case-based pedagogy and the professional development of teachers. Teaching and Teacher Education, 11(3), 203-214. https://doi.org/10.1016/0742-051x(94)00027-4

Harrington, H. L., \& Garrison, J. W. (1992). Cases as shared inquiry: A dialogical model of teacher preparation. $\begin{array}{llll}\text { American Educational } & \text { 715-735. }\end{array}$ https://doi.org/10.3102/00028312029004715

Hartfield, P. J. (2010). Reinforcing Constructivist Teaching in Advanced Level Biochemistry through the Introduction of Case-Based Learning Activities. Journal of Learning Design, 3(3), 20-31. https://doi.org/10.5204/jld.v3i3.59 
Hemphill, M. A., Richards, K. A. R., Gaudreault, K. L., \& Templin, T. J. (2015). Prospective teacher perspectives of case-based learning in physical education teacher education. European Physical Education Review, 21(4), 432-450. https://doi.org/10.1177/1356336X15579402

Herrington, J., \& Oliver, R. (1995). Critical characteristics of situated learning: Implications for the instructional of multimedia. In: ASCILITE 1995 Conference, 3 - 7 December 1995, University of Melbourne, Melbourne pp. 253-262.

Honebein, P. C. (1996). Seven goals for the design of constructivist learning environments. In B. G. Wilson (Ed.), Constructivist learning environments: Case studies in instructional design (pp. 11-24). New Jersey, $\mathrm{NJ}$ : Educational Technology.

Jonassen, D. H. (1991). Objectivism versus constructivism: Do we need a new philosophical paradigm? Educational Technology Research and Development, 39(3), 11-12. https://doi.org/10.1007/bf02296434

Kantar, L. D. (2013). Demystifying instructional innovation: The case of teaching with case studies. Journal of the Scholarship of Teaching and Learning, 13(2), 101-115.

Kim, H., \& Hannafin, M. J. (2008). Situated case-based knowledge: An emerging framework for prospective teacher learning. Teaching and Teacher Education, 24(7), 1837-1845. https://doi.org/10.1016/j.tate.2008.02.025

Kim, S., Phillips, W. R., Pinsky, L., Brock, D., Phillips, K., \& Keary, J. (2006). A conceptual framework for developing teaching cases: A review and synthesis of the literature across disciplines. Medical Education, 40(9), 867-876. https://doi.org/10.1111/j.1365-2929.2006.02544.x

Koury, K., Hollingsead, C., Fitzgerald, G., Miller, K., Mitchem, K., Tsai, H., \& Zha, S. (2009). Case-based instruction in different delivery contexts: The impact of time in cases. Journal of Interactive Learning Research, 20(4), 445-467.

Krupat, E., Richards, J. B., Sullivan, A. M., Fleenor, T. J., \& Schwartzstein, R. M. (2016). Assessing the effectiveness of case-based collaborative learning via randomized controlled trial. Academic Medicine, 91(5), 723-729. https://doi.org/10.1097/acm.0000000000001004

Latourelle, S. M., Poplawsky, A., Shmaefsky, B., \& Musante, S. (2012). Using socio-scientific issues-based instruction. New York: Pedagogy in Action.

Levin, B. B. (1995). Using the case method in teacher education: the role of discussion and experience in teachers thinking about cases. Teaching \& Teacher Education, 11, 63-79.

Levin, B. B. (2001). Energizing teacher education and professional development with problem-based learning. ASCD.

Lundeberg, M. A., Levin, B. B., \& Harrington, H. L. (Eds.). (1999). Who learns what from cases and how?: The research base for teaching and learning with cases. Mahwah, NJ: Lawrence Erlbaum. https://doi.org/10.4324/9781410602381

Lundeberg, M. A., \& Yadav, A. (2006). Assessment of case study teaching: Where do we go from here? Part II. Journal of College Science Teaching, 35(6), 8.

Mazzolini, M., \& Maddison, S. (2007). When to jump in: The role of the instructor in online discussion forums. Computers \& Education, 49, 193-213.

McLoughlin, D., \& Mynard, J. (2009). An analysis of higher-order thinking in online discussions. Innovations in Education and Teaching International, 46, 147-160. https://doi.org/10.1080/14703290902843778

Merseth, K. K. (1996). Cases and case methods in teacher education. Handbook of research on teacher education, 2, 722-744. https://doi.org/10.1177/002248719104200402 
Mitchem, K., Fitzgerald, G., Hollingsead, C., Koury, K., Miller, K., \& Tsai, H. H. (2008). Enhancing case-based learning in teacher education through online discussions: Structure and facilitation. Journal of Interactive Learning Research, 19(2), 331-349. Retrieved from https://www.learntechlib.org/primary/p/22945/

Morrow, C. B., Epling, J. W., Terán, S., Sutphen, S. M., \& Novick, L. F. (2003). Future applications of case-based teaching in population-based prevention. American Journal of Preventive Medicine, 24(4), 166-179. https://doi.org/10.1016/s0749-3797(03)00040-0

Mostert, M. P. (2007). Challenges of case-based teaching. The Behavior Analyst Today, 8(4), 434-442. https://doi.org/10.1037/h0100632

Sadler, T. D. (2004). Informal reasoning regarding socioscientific issues: A critical review of research. Journal of Research in Science Teaching: The Official Journal of the National Association for Research in Science Teaching, 41(5), 513-536. https://doi.org/10.1002/tea.20009

Sadler, T. D. (2014). Assessment of socio-scientific reasoning: Linking progressive aims of science education to the realities of modern education. In M.P. Mueller, D.J. Tippins, \& A.J. Stewart (Eds.) Assessing schools for generation $R$ (responsibility) (pp. 101-113). New York: Springer. https://doi.org/10.1007/978-94-007-2748-9_8

Saltan, F., Özden, M. Y., \& Kiraz, E. (2016). Design and Development of an Online Video Enhanced Case-Based Learning Environment for Teacher Education. Journal of Education and Practice, 7(11), 14-23.

Savery, J. R., \& Duffy, T. M. (1996). Problem based learning: An instructional model and its constructivist framework. In B. G. Wilson (Ed.), Constructivist learning environments: Case studies in instructional design (pp 31-38). New Jersey, NJ: Educational Technology.

Schunk, D. H. (2008). Learning theories: An educational perspective (5th. ed.). Upper Saddle River, NJ: Merrill/Prentice Hall.

Sen, M. (2017). Case-based learning for enhancing prospective elementary teachers' conceptualization of socioscientific issues and socioscientific issue-based teaching (Doctoral dissertation). Retrieved from http://purl.galileo.usg.edu/uga_etd/sen_mutlu_201708_phd

Shulman, J. H. (1991). Revealing the mysteries of teacher-written cases: Opening the black box. Journal of Teacher Education, 42, 250-262. https://doi.org/10.1177/002248719104200403

Shulman, L. (1992). Toward a pedagogy of cases. In J. Shulman, Case methods in teacher education (pp. 129). New York, NY: Teachers College Press.

Stake, R. E. (1995). The art of case study research. Thousand Oaks, CA: Sage Publications, Inc.

Strangeways, A., \& Papatraianou, L. H. (2016). Case-Based Learning for Classroom Ready Teachers: Addressing the Theory Practice Disjunction through Narrative Pedagogy. Australian Journal of Teacher Education, 41(9), 117-134. https://doi.org/10.14221/ajte.2016v41n9.7

Strauss, A., \& Corbin, J. (1994). Grounded theory methodology. Handbook of qualitative research, 17(1), 273285.

Sursock, A., Smidt, H., \& Davies, H. (2010). Trends 2010: A decade of change in European Higher Education. Brussels: European University Association.

Tippins, D. J., Koballa, T. J., \& Payne, B. D. (2002). Learning from cases: unraveling the complexities of elementary science teaching. Boston, MA: Allyn and Bacon.

Tippins, D. J., Nichols, S. E., \& Dana, T. M. (1999). Exploring novice and experienced elementary teachers' science teaching and learning referents through video-cases. Research in Science Education, 29(3), 331352. https://doi.org/10.1007/bf02461597 
Tobin, K., \& Tippins, D. (1993). Constructivism as a referent for teaching and learning. In W. W. Cobern (Ed.), The practice of constructivism in science education (pp. 3-22). Mahwah, NJ: Lawrence Erlbaum. https://doi.org/10.1017/cbo9780511752865.013

Weil, S., McGuigan, N., \& Kern, T. (2011). The usage of an online discussion forum for the facilitation of casebased learning in an intermediate accounting course: A New Zealand case. Open Learning: The Journal of Open, Distance and e-Learning, 26(3), 237-251. https://doi.org/10.1080/02680513.2011.611685

Wilson, B. G. (1996). What is a constructivist learning environment? In B. G. Wilson (Ed.), Constructivist learning environments: Case studies in instructional design (pp. 3-10), New Jersey, NJ: Educational Technology.

Yoon, S., Pedretti, E., Pedretti, L., Hewitt, J., Perris, K., \& Van Oostveen, R. (2006). Exploring the use of cases and case methods in influencing elementary preservice science teachers' self-efficacy beliefs. Journal of Science Teacher Education, 17(1), 15-35. https://doi.org/10.1007/s10972-005-9005-0

Zottmann, J. M., Goeze, A., Frank, C., Zentner, U., Fischer, F., \& Schrader, J. (2012). Fostering the analytical competency of pre-service teachers in a computer-supported case-based learning environment: A matter of perspective?. Interactive Learning Environments, 20(6), 513-532. https://doi.org/10.1080/10494820.2010.539885

Correspondence: Mutlu Şen Akbulut, Boğaziçi University, Turkey. E-mail: mutlu.sen@boun.edu.tr 